(c) Group of authors, 2018

UDC 616.72-002.77:615

DOI - https://doi.org/10.14300/mnnc.2018.13078

ISSN - 2073-8137

\title{
BIOLOGICAL THERAPY OF RHEUMATOID ARTHRITIS: IS IT A REAL PREDICTION OF EFFICACY?
}

Koroy P. V., Sarithala V. J., Yagoda A. V.

Stavropol State Medical University, Russian Federation

\section{БИОАОГИЧЕСКАЯ ТЕРАПИЯ РЕВМАТОИАНОГО АРТРИТА: РЕААЬНА АИ ПРЕАИКЦИЯ ЭФФЕКТИВНОСТИ?}

\author{
П. В. Корой, В. А. Саритхала, А. В. ЯгоАа \\ Ставропольский госуАарственный меАицинский университет, \\ Российская ФеАерация
}

Relationship of intercellular adhesion molecule-1 (ICAM-1), vascular cell adhesion molecule-1 (VCAM-1), plateletendothelial cell adhesion molecule-1 (PECAM-1), E-, P- and L-selectins blood levels with results of three-monthly combination treatment by biological agents and methotrexate was studied in 35 patients with rheumatoid arthritis ( 29 women, 6 men) at age from 40 to 66 with previous noneffective methotrexate treatment. Tocilizumab was applied in 20 patients, in 15 cases etanercept was used. The moderate effect of treatment was observed in $74.3 \%$ of cases, remission or low activity of rheumatoid arthritis were reached in $22.9 \%$ of patients, 9 patients were non-responders. Increase of blood concentration of all immunoglobulins superfamily molecules and of P-selectin was observed in rheumatoid arthritis. After 3 months of therapy decrease in VCAM-1, PECAM-1 blood levels and normalization of ICAM-1, P-selectin values were observed, especially in cases of effective treatment, in non-responders there was reduction only of ICAM-1 levels. The favorable response to treatment was associated with high initial levels of ICAM-1, PECAM-1 and low levels of P-selectin in blood that opens new possibilities of use of adhesion molecules in prediction of successful therapy of RA.

Keywords: rheumatoid arthritis, immunoglobulins superfamily molecules, selectins, biological therapy, prediction of efficacy

У 35 больных ревматоидным артритом (29 женщин, 6 мужчин) в возрасте от 40 до 66 лет с предшествующей неэффективной терапией метотрексатом изучена взаимосвязь плазменного содержания молекул межклеточной адгезии-1 (ICAM-1), адгезии сосудистого эндотелия-1 (VCAM-1), адгезии эндотелия и тромбоцитов-1 (PECAM-1), E-, P- и L-селектинов с результатами трехмесячного комбинированного лечения биологическими препаратами и метотрексатом. У 20 пациентов применялся тоцилизумаб, в 15 случаях назначен этанерцепт. Удовлетворительный эффект терапии наблюдался в 74,3 \% случаев, ремиссия или низкая активность ревматоидного артрита достигнуты у 22,9 \% больных, 9 пациентов являлись нон-респондерами. При ревматоидном артрите отмечалась увеличенная концентрация в крови молекул суперсемейства иммуноглобулинов и Р-селектина. Через 3 месяца терапии наблюдалось снижение содержания VCAM-1, PECAM-1 в крови и нормализация значений ICAM-1, Р-селектина, особенно в случаях эффективного лечения, у нон-респондеров происходило уменьшение значений только ICAM-1. Благоприятный ответ на лечение был связан с высокими исходными уровнями ICAM-1, РЕСАМ-1 и низкими показателями Р-селектина в крови, что открывает новые возможности использования молекул адгезии в предикции успешной терапии PA.

Ключевые слова: ревматоидный артрит, молекулы суперсемейства иммуноглобулинов, селектины, биологическая терапия, предикция эффективности

For citation: Koroy P. V., Sarithala V. J., Yagoda A. V. BIOLOGICAL THERAPY OF RHEUMATOID ARTHRITIS: IS REAL PREDICTION OF EFFICACY? Medical News of North Caucasus. 2018;13(3):463-467.

DOI - https://doi.org/10.14300/mnnc.2018.13078

Для цитирования: Корой П. В., Саритхала В. Д., Ягода А. В. БИОЛОГИЧЕСКАЯ ТЕРАПИЯ РЕВМАТОИДНОГО АРТРИТА: РЕАЛЬНА ЛИ ПРЕДИКЦИЯ ЭФФЕКТИВНОСТИ? МедицинскиЙ вестник Северного Кавказа. 2018;13(3):463467. DOI - https://doi.org/10.14300/mnnc.2018.13078

$\begin{array}{ll}\text { ACCP } & \text { - Antibody To Cyclic Citrullinated Peptide } \\ \text { AC } & \text { - Accuracy } \\ \text { CI } & \text { - Confidence Interval } \\ \text { DAS } & \text { - Disease Activity Score } \\ \text { NSAIDs - Non-Steroid Anti-Inflammatory Drugs }\end{array}$

DMARDs - Disease Modifying Antirheumatic Drugs

EULAR - European League Against Rheumatism

ICAM-1 - Intercellular Adhesion Molecule-1

NPV - Negative Predictive Value

OR - Odds Ratio 


\author{
PECAM-1 - Platelet Endothelial Cell Adhesion Molecule-1 \\ PPV - Positive Predictive Value \\ RA - Rheumatoid Arthritis \\ RF - Rheumatoid Factor
}

\author{
Se - Sensitivity \\ Sp - Specificity \\ TNF - Tumor Necrosis Factor \\ VCAM-1 - Vascular Cell Adhesion Molecule-1
}

\section{$\mathrm{T}$} The aim of therapy of RA is to achieve remission or to reduce the disease activity, leading to decreased destruction and dysfunction of joints, conservation of quality of life and increased duration of life of the patients. In cases with less effectiveness of therapy with synthetic DMARDs, the question of prescription of other drugs, or addition of biological agents is to be decided, especially with the presence of unfavorable prognostic factors, among which are large number of inflamed joints, high level of acute phase proteins, presence of RF and/or ACCP [1].

Biological preparations with their characteristic ability to block the activity of cytokines, chemokines and other immunological proteins, as well as inhibition of intercellular interactions were widely used in therapy of RA [1]. Good and moderate clinical response on therapy with TNF- $\alpha$ inhibitors (EULAR criteria) was noticed in 52-61\% and 28-34\% cases of RA respectively [2]. Unlike synthetic DMARDs, therapy with etanercept more often leads to remission or decrease in the activity of RA: its positive effect, which was much higher after 2-year therapy was noticed (64\% and $50 \%$ cases respectively) [3]. Analogical results were obtained in relation of therapy with tocilizumab when compared to anti TNF- $\alpha$ agents [4]. At the same time, in the recent years, decrease in effectiveness of anti-cytokine therapy was noticed, which was depended on number of factors [5], including one related with the absence of individual indication for its prescription.

Activation/dysfunction of endothelium plays key role in the pathogenesis of RA, its manifestation, including the hyperproduction of adhesion molecules [6-8], responsible for the cellular migration, accumulation of immune cells and fibroblasts involved in the processes of destruction and proliferation of synovial membrane. Thus, in patients with RA increased plasma concentrations of molecules of immunoglobulin superfamily and selectins in severe course of disease was noticed, including with systemic (hematological) manifestations $[6,7,9,10]$, which was not shared by other researchers [8].

The possibility of correction of endothelial dysfunction with modern DMARDs, including genetically engineered biological preparations, was not completely studied. Although it is known that proinflammatory cytokines, which are main target of these preparations, are one of the stimulators of adhesion molecules. Blocking TNF- $\alpha$ improves endothelial functioning in RA, by decreasing the levels of ICAM-1, VCAM-1, PECAM-1, E-, P-selectins in blood, supressing the activation of endothelium and migration of immune cells to synovial membrane [11, 12]. Combination of etanercept and methotrexate lead to sustainable decline in the concentration of adhesins in blood, proportionally decreasing the activity of disease [13]. At the same time, evidences of existence of such interactions in patients with RA are insufficient [14]. Until now, effect of tocilizumab on adhesive status in patients with RA was not studied; evaluation of the capability of adhesins in blood in these patients as predictors of effectiveness of biological therapy was not carried out. Meanwhile, it was obvious that definition of contingency of adhesion molecules with results of treatment of RA and evaluation of features of these associations may be useful in deciding the problems of prognosis of therapy.

Aim of the research was to evaluate the relationship of soluble adhesion molecules with results of treatment of RA with biological preparations.
Material and Methods. Thirty five patients with RA (29 women, 6 men) of age from 40 to 66 years were included in the research. Inclusion criteria: patients with RA of age 18 and elder, consent for participation in the research, intake of NSAIDs or glucocorticoids in stable doses for not less than 4 weeks. Under exclusion criteria were, intake of genetically engineered biological preparations in anamnesis, inflammatory diseases of joints of other etiology, acute and in the period of exacerbation chronic somatic diseases, malignant neoplasms, transplantation of organs in anamnesis, major surgery or infection in the past 12 weeks, alcoholic or drug addiction, psychological diseases, denial of participation in research. Control group constituted 70 practically healthy people, compatible of sex, age and physical development.

Diagnosis of RA was established in accordance with the ACR/EULAR (2010) criteria, clinical characteristics of the patients were defined according to the classification of association of rheumatologists of Russia. Among patients prevailed women $(82.9 \%)$, with late stage of disease $(97.1 \%)$ and high disease activity $(74.3 \%)$. Duration of joint syndrome constituted $13.57 \pm 1.83$ years. Mean values of index DAS28 were 5.78 \pm 0.12 . RF and ACCP in blood were found in $94.3 \%$ and $91.4 \%$ of patients respectively. Most of the patients were diagnoses with III X-ray stage $(85.7 \%)$ and III functional class of the disease.

At the moment of inclusion in the research, all patients were prescribed methotrexate in stable dose of 10$20 \mathrm{mg}$ per week for not less than 12 months along with the combination of folic acid. Aside from that, $85.7 \%$ of patients used NSAIDs (diclofenac, nimesulide or meloxicam) in stable doses or "on demand" and/or glucocorticoids (prednisolone or methylprednisolone) in low doses (54.3\% patients).

Due to lack of response to the treatment (in comparison with data prior to the intake of methotrexate) modification of treatment was made with the combination of methotrexate and biological agents (in 20 patients tocilizumab was used, in 15 cases etanercept was prescribed). Tocilizumab was introduced intravenously in the form of infusion at a dose of $8 \mathrm{mg} / \mathrm{kg}$ body weight, once in 4 weeks, etanercept subcutaneously of $50 \mathrm{mg}$ once in a week. Effectiveness of combination therapy was evaluated after 3 months, in accordance with EULAR criteria.

Study of plasma levels of molecules of immunoglobulin superfamily (ICAM-1, VCAM-1, PECAM-1) and selectins (E-, P-, L-) at the baseline and in dynamics of 3-month treatment was done by ELISA method using kits of «Bender MedSystems GmbH» (Austria).

Research was corresponded to the requirements of Helsinki declaration of world medical association on ethical principles for conducting medical research with the participation of humans as subjects. Patients and individuals in control group were given information consent on conducting the research, which was approved by ethical committee of the university.

Statistical analysis of the obtained results was carried out with the help of software program adapted for medical-biological research (IBM SPSS Statistics 24). Two sample or paired Students t-criteria, criteria of Newman-Keuls, Mann-Whitney, Kruskal-Wallis, Dane, and Wilcoxon were evaluated. Odds ratio and its $95 \%$ confidence interval were studied. Diagnostic valuation of indicators was determined by sensitivity and specificity, 
positive and negative predictive value, accuracy, expressed in percentages. ROC-analysis had applied with defining the area under curve (AUC). Results were considered reliable with the level of significance of differences $p<0.05$.

Results and Discussion. During the process of treatment, significant decrease in the value of DAS28, number of tender and swollen joints, ESR, C-reactive protein, improvement of general health assessment of patient had taken place. Satisfactory effect from 3-month treatment was observed in $74.3 \%$ of cases, including remission or low activity of RA achieved in $22.9 \%$ of the patients; 9 patients were non-responders, which corresponded with the previously received data [3, 4]. In patients with positive results of treatment in dynamics, very low values of DAS28, number of tender and swollen joints, levels of C-reactive protein were observed.

Prior to the administration of biological agents, in patients with RA, increased concentrations of all molecules of immunoglobulin superfamily and levels of $P$-selectin in blood were present $(p<0.05)$ irrelevant of sex and age (Table 1). In dynamics of 12-week combination therapy, decline in plasma levels of ICAM-1, VCAM-1, PECAM-1and P-selectin $(p<0.05)$ had taken place, in which levels of VCAM- 1 and PECAM- 1 in the course of treatment remained increased, and concentration of ICAM-1 and P-selectin in blood came to normal levels.

In patients with satisfactory results of treatment, normalization of indicators of ICAM-1, P-selectin and decline in the levels of VCAM-1, PECAM-1 in blood not reaching to the control levels were observed. In cases without any effect, decrease in the values of soluble ICAM-1 and inertness in the increased levels of remaining adhesins was observed, whereas concentration of ICAM1, VCAM-1 and P-selectin became even higher than in group of responders. In cases with beneficial effect on 12-weeks therapy very high pretreatment levels of ICAM-1 and PECAM-1 and very low levels of P-selectin in blood in comparison with non-responders were observed (Table 2 ).

Blood levels of adhesion molecules in dynamics of biological therapy of rheumatoid arthritis (M \pm SE/Me (Q1; Q3))

\begin{tabular}{|l|c|c|}
\hline \multirow{2}{*}{$\begin{array}{c}\text { Adhesion } \\
\text { molecules } \\
(\mathrm{ng} / \mathrm{ml})\end{array}$} & \multicolumn{2}{|c|}{ Groups } \\
\cline { 2 - 3 } E-selectin & $33.71 \pm 1.24$ & $\frac{34.11 \pm 2.45}{35.74 \pm 2.58}$ \\
\hline P-selectin & $91.83 \pm 3.14$ & $\frac{140.46 \pm 9.04}{99.89 \pm 9.79}{ }^{*}$ \\
\hline L-selectin & $\begin{array}{c}3490 \\
(2650 ; 4749)\end{array}$ & $\frac{3669(3460 ; 4222)}{3726(3283 ; 3966)}$ \\
\hline ICAM-1 & $499.04 \pm 20.24$ & $\frac{1101.46 \pm 63.87}{527.26 \pm 30.46}{ }^{*}$ \\
\hline VCAM-1 & $\begin{array}{c}787.50 \\
(545 ; 1120)\end{array}$ & $\frac{2607(1220 ; 6000)}{2740(1531 ; 4000)} *, x$ \\
\hline PECAM-1 & $55.90 \pm 3.87$ & $\frac{116.00 \pm 8.03}{*} *$ \\
\hline
\end{tabular}

Note: in numerator - parameters before treatment, in denominator - parameters after treatment. * $-p<0.05$ in comparison with control; ${ }^{x}-p<0.05$ in dynamic of treatment.

Influence of biological therapy results on blood levels of adhesion molecules (M $\pm S E / M e(Q 1 ; Q 3))$

\begin{tabular}{|c|c|c|c|}
\hline \multirow{3}{*}{$\begin{array}{c}\text { Adhesion } \\
\text { molecules } \\
(\mathrm{ng} / \mathrm{ml})\end{array}$} & \multicolumn{3}{|c|}{ Groups } \\
\hline & \multirow{2}{*}{ Control } & \multicolumn{2}{|c|}{ RA } \\
\hline & & Effect $\ll+», n=26$ & Effect $\ll-», n=9$ \\
\hline E-selectin & $33.71 \pm 1.24$ & $\frac{33.23 \pm 2.86}{35.42 \pm 3.11}$ & $\frac{36.67 \pm 4.91}{36.67 \pm 4.79}$ \\
\hline P-selectin & $91.83 \pm 3.14$ & $\frac{125.85 \pm 7.90}{83.42 \pm 8.96}{ }^{*}, \#$ & $\frac{182.67 \pm 22.09}{147.44 \pm 21.87} *$ \\
\hline L-selectin & $3490(2650 ; 4749)$ & $\frac{3655(3460 ; 4222)}{3582.5(3104 ; 4140)}$ & $\frac{3722(3394 ; 3972)}{3945(3676 ; 3955.5)}$ \\
\hline ICAM-1 & $499.04 \pm 20.24$ & $\frac{1184.42 \pm 76.68}{454.23 \pm 19.61} \times, x_{,}^{*}$ & $\frac{861.78 \pm 68.42 *}{738.22 \pm 66.14 *, x}$ \\
\hline VCAM-1 & $787.50(545 ; 1120)$ & $\begin{array}{c}2706(1398 ; 6000){ }^{*} \\
2332(1531 ; 3681) *, x, \#\end{array}$ & $\frac{2000(926.5 ; 4000)}{4000(1515 ; 4126)} *$ \\
\hline PECAM-1 & $55.90 \pm 3.87$ & $\frac{124.77 \pm 9.83}{82.08 \pm 6.15} *$, , & $\frac{90.67 \pm 9.22}{95.66 \pm 7.77} *$ \\
\hline
\end{tabular}

Note: in numerator - parameters before treatment, in denominator - parameters after treatment. ${ }^{*}-p<0.05$ in comparison with control; $^{x}-p<0.05$ in dynamic of treatment; ${ }^{\#}-p<0.05$ between groups of patients.

Threshold levels of ICAM-1 more than $886 \mathrm{ng} /$ $\mathrm{ml}$, PECAM-1 higher than $101 \mathrm{ng} / \mathrm{ml}$, E-selectin lower than $40 \mathrm{ng} / \mathrm{ml}$ and $\mathrm{P}$-selectin less than $176 \mathrm{ng} / \mathrm{ml}$ were related with positive effect of biological therapy; values of ICAM-1 and P-selectin were characterized with high diagnostic accuracy in delineation of results of therapy and levels of PECAM-1 had moderate accuracy (Table 3).

Diagnostic significance of adhesion molecules in prediction of biological therapy results

Table 3

\begin{tabular}{|l|c|c|c|c|c|c|c|}
\hline $\begin{array}{c}\text { Adhesion molecules } \\
(\mathrm{ng} / \mathrm{ml})\end{array}$ & $\begin{array}{c}\text { OR } \\
(95 \% \mathrm{CI})\end{array}$ & $\begin{array}{c}\text { AUC } \\
(\mathrm{M} \pm \mathrm{SE})\end{array}$ & $\begin{array}{c}\text { Se } \\
(\%)\end{array}$ & $\begin{array}{c}\text { Sp } \\
(\%)\end{array}$ & $\begin{array}{c}\text { PPV } \\
(\%)\end{array}$ & $\begin{array}{c}\text { NPV } \\
(\%)\end{array}$ & $\begin{array}{c}\text { Ac } \\
(\%)\end{array}$ \\
\hline E-selectin $\leq 40$ & $5.43(1.06-27.83)$ & $0.58 \pm 0.11$ & 73.1 & 66.7 & 86.4 & 46.2 & 71.4 \\
\hline P-selectin $\leq 176$ & $15(2.13-105.62)$ & $0.74 \pm 0.09$ & 92.3 & 55.6 & 85.7 & 71.4 & 82.9 \\
\hline L-selectin $\leq 3669$ & $2.73(0.56-13.37)$ & $0.54 \pm 0.11$ & 57.7 & 66.7 & 83.3 & 35.3 & 60.0 \\
\hline ICAM-1 $\geq 886$ & $42(4.98-354.54)$ & $0.83 \pm 0.07$ & 92.3 & 77.8 & 92.3 & 77.8 & 88.6 \\
\hline VCAM-1 $\geq 2490$ & $2.81(0.59-13.34)$ & $0.55 \pm 0.11$ & 69.2 & 55.6 & 81.8 & 38.5 & 65.7 \\
\hline PECAM-1 $\geq 101$ & $15.11(1.62-140.58)$ & $0.73 \pm 0.09$ & 65.4 & 88.9 & 94.4 & 47.1 & 71.4 \\
\hline
\end{tabular}


Irrelevant of type of biological treatment (tocilizumab, etanercept), normalization of initially increased plasma levels of ICAM-1 and P-selectin, decrease in blood concentration of PECAM-1 and tendency to decrease in the values of VCAM-1 were observed. Values of E- and L-selectins remained normal after treatment with any of the drugs.

In 15 patients with positive results of intaking tocilizumab, normalization of initially increased values of ICAM-1 and P-selectin, decline in the increased levels of PECAM-1 (not reached up to control levels) and tendency for decreasing in the blood concentrations of VCAM-1 were observed. In cases without any effect from tocilizumab, significant decrease (not normalization) in the levels of soluble ICAM- 1 and absence in dynamics of remaining indicators were noticed, whereas the values of ICAM-1 and P-selectin became higher than in the group of responders. Patients with beneficial effects on treatment with tocilizumab had very high initial (prior to its intake) levels of ICAM-1, PECAM- 1 and very low concentrations of $\mathrm{P}$-selectin in blood in comparison to non-responders.

The values of ICAM- 1 more than $892 \mathrm{ng} / \mathrm{ml}$ (OR $56 ; 95 \% \mathrm{Cl}(2.83-1109.43))$ and E-selectin lower than $40 \mathrm{ng} / \mathrm{ml}$ (OR 26; $95 \% \mathrm{Cl}(1.84-367.70)$ ) testifies on high possibility of attaining results of treatment with tocilizumab, which are characterized with high diagnostic accuracy ( 90 и $85 \%$ respectively) in delineation of results of treatment with this medicine.

Effective treatment with etanercept in 11 patients facilitated to normalization of initially increased values of ICAM-1, PECAM-1 and P-selectin, even in the absence of dynamics of values of VCAM-1. In non-responders, normalization in blood concentrations of ICAM-1 was observed in absence of dynamics of increased values of VCAM-1, PECAM-1 and P-selectin. Levels of ICAM-1, VCAM-1 and P-selectin after treatment remained very higher than in group of responders. In cases with successful treatment by etanercept, very high initial levels of ICAM- 1 and very low values of P-selectin in blood were determined. Dynamics in concentrations of $\mathrm{E}$ - and L-selectins, regardless of treatment results, were not found.

Indicators of ICAM-1 higher than $886 \mathrm{ng} / \mathrm{ml}$ (OR 30; $95 \% \mathrm{Cl}(1.41-638.15))$ were involved with achieving positive results of treatment with etanercept and characterized with high diagnostic accuracy $(86.7 \%)$ in delineation of treatment results.

An important role in the activation and dysfunction of endothelium in RA related with increase in levels of soluble adhesion molecules $[6,8,15]$ illustrates the capability of DMARDs to decrease their expression and in result decrease inflammatory infiltration in synovial tissue. From the results of P. A. Klimiuk et al. [15], initially increased blood levels of ICAM-1, VCAM- 1 and E-selectin were declined after 6-month treatment of early RA with methotrexate, which was noticed with decreased number of tender and swollen joints, values of ESR, C-reactive protein, DAS. TNF- $\alpha$ antagonists (infliximab, adalimumab or etanercept) are capable of decreasing activity of RA by levelling the endothelial dysfunction, inhibition of synthesis of adhesins and vascular endothelial growth factor [11-13, 16, 17]. Certolizumab, in vitro, suppressed TNF- $\alpha$ induced expression of adhesins and secretion of chemokines by endotheliocytes [18], and intake of inhibitors of aldosterone and angiotensin converting enzyme in patients with RA capable of highly expressed decline in the levels of ICAM-1, vascular endothelial growth factor, TNF- $\alpha$, acute phase proteins in blood, and improved indicators of vasodilation [19].

Beneficial involvement of treatment procedures on the levels of adhesion molecules in RA are likely related with suppression in production of proinflammatory cytokines [17], since expression of adhesins on significant extent is related by its effects, with decreased oxidative stress [20] and with decreased activity of angiotensin II and aldosterone [19].

Absence of normalization in values of VCAM-1 and PECAM-1 in patients responding to treatment and inertness in values of most adhesins in non-responders may characterized by the retention of pathomorphological shifts in the form of synovial membrane hyperplasia, bone-cartilage destruction [21] as a main skip out from the treatment.

Due to high specificity of unsatisfactory results in treatment of RA, its optimization remains as an important problem. At the same time reliable markers of successful treatment of RA, including that of biological preparations are not developed yet. As a predictor of successful response on treatment of refractory RA with leflunomide and methotrexate, initial values of DAS28 less than 5.5 were proposed [22]. Short duration of RA and low values of DAS28 resulted in stable remission as a result of treatment with tocilizumab [23]. Positive results in treatment of RA by TNF- $\alpha$ inhibitors are associated with high educational level in patients [24], and predictors of response on methotrexate lied high levels of RF and ACCP [25]. Successful application of TNF- $\alpha$ inhibitors was associated with prior intake of methotrexate, NSAIDs, and absence of smoking.

For the prediction of results in treatment, we propose to use complex of biomarkers, including adhesion molecules. According to our data, threshold level of ICAM-1, PECAM-1, E-selectin and P-selectin, evaluated prior to the treatment, accompanied by, positive response on biological treatment in RA by $42,15,5$ and 15 times respectively very higher, than with alternative indicators of biomarkers and are character-ized by adequate diagnostic relevance in delineating good and unsatisfactory results of treatment.

Thus, biological therapy provides beneficial influence on adhesion function of endothelium in RA and capable of decreasing inflammatory effects of disease. Analysis of adhesins profile, as it turned out having predictive value in evaluation of results of RA treatment, opens new forecasting capabilities of response on treatment, allowing, including that to distinguish the risk group of unsatisfactory results.

\section{Conclusions}

1. In RA, increased blood concentration of immunoglobulin superfamily molecules and P-selectin irrelevant of sex and age of patients was observed.

2. At the end of 3-month biological therapy of RA (tocilizumab, etanercept) decrease in concentration of VCAM-1, PECAM-1 in blood and normalization of ICAM-1, $P$-selectin were noticed, especially in cases with effective treatment; in non-responders decrease in levels of only ICAM-1 had taken place.

3. Cases with beneficial response on biological agents were interrelated with very high initial levels of ICAM-1, PECAM-1 and very low concentration of P-selectin in blood, which can be used for prediction of treatment of RA.

\section{Disclosures:}

The authors declare no conflict of interest. 


\section{References}

1. Smolen J. S., Landewé R., Bijlsma J., Burmester G., Chatzidionysiou K. [et al.] EULAR recommendations for the management of rheumatoid arthritis with synthetic and biological disease-modifying antirheumatic drugs: 2016 update. Ann. Rheum. Dis. 2017;76(6):960-977. https://doi.org/10.1136/annrheumdis-2016-210715

2. Li N., Betts K. A., Messali A. J., Skup M., Garg V. Real-world effectiveness of biologic disease-modifying antirheumatic drugs for the treatment of rheumatoid arthritis after etanercept discontinuation in the United Kingdom, France, and Germany. Clin. Ther. 2017;39(8):1618-1627. https://doi.org/10.1016/i.clinthera.2017.06.009

3. Kotak S., Mardekian J., Horowicz-Mehler N., Shah A., Burgess A. [et al.] Impact of etanercept therapy on disease activity and health-related quality of life in moderate rheumatoid arthritis patients population from a National British Observational Cohort. Value Health. 2015;18(6):817-823. https://doi.org/10.1016/j.jval.2015.05.005

4. Kihara M., Davies R., Kearsley-Fleet L., K. Watson D., Lunt M. [et al.] Use and effectiveness of tocilizumab among patients with rheumatoid arthritis: an observational study from the British Society for Rheumatology Biologics Register for rheumatoid arthritis. Clin. Rheumatol. 2017:36(2):241-250.

https://doi.org/10.1007/s10067-016-3485-5

5. Gremese E., Carletto A., Padovan M., Atzeni F., Raffeiner $\mathrm{B}$. [et al.] Obesity and reduction of the response rate to anti-tumor necrosis factor- $\alpha$ in rheumatoid arthritis: an approach to a personalized medicine. Arthritis Care Res. 2013;65(1):94-100. https://doi.org/10.1002/acr.21768

6. Klimek E., Skalska A., Kwaśny-Krochin B., Surdacki A., Sulicka J. [et al.] Differential associations of inflammatory and endothelial biomarkers with disease activity in rheumatoid arthritis of short duration. Mediators Inflamm. 2014;2014:681635. https://doi.org/10.1155/2014/681635

7. Koroy P. V., Sarithala V. D., Yagoda A. V. Soluble molecules of immunoglobulins superfamily in rheumatoid arthritis. Medical news of North Caucasus. 2017:12(3):256-260. https://doi.org/10.14300/mnnc.2017.12092

8. Södergren A., Karp K., Boman K., Eriksson C., Lundström E. [et al.] Atherosclerosis in early rheumatoid arthritis: very early endothelial activation and rapid progression of intima media thickness. Arthritis Res. Ther. 2010;12(4):R158. https://doi.org/10.1186/ar3116

9. Yagoda A. V., Sarithala V. J., Koroy P. V. Anemia in rheumatoid arthritis: correlation with hepcidin and adhesion molecules. Meditsinskii vestnik Severnogo Kavkaza Medical News of North Caucasus. 2018;13(2):338-342. (In Russ.). https://doi.org/10.14300/mnnc.2018.13044

10. Sarithala V. J., Koroy P., Yagoda A. Variations in levels of intercellular adhesion molecule- 1 with disease course, in rheumatoid arthritis patients. J. Clin. Diagnostic Res. 2018;12(9):18-21. https://doi.org/10.7860/ JCDR/2018/35302.12044

11. Gonzalez-Gay M. A., De Matias J. M., Gonzalez-Juanatey C., Garcia-Porrua C., Sanchez-Andrade A. [et al.] Anti-tumor necrosis factor-alpha blockade improves insulin resistance in patients with rheumatoid arthritis. Clin. Exp. Rheumatol. 2006:24(1):83-86

12. Gonzales-Gay M. A., Garcia-Unzueta M. T., de Matias J. M., Gonzalez-Juanatey C., Garcia-Porrua C. [et al.] Influence of anti-TNF-a infliximab therapy on adhesion molecules associated with atherogenesis in patients with rheumatoid arthritis. Clin. Exp. Rheumatol. 2006; 24(4):373-379.
13. Klimiuk P. A., Sierakowski S., Domyslawska I., Chwiecko J Effect of etanercept on serum levels of soluble cell adhesion molecules (sICAM-1, sVCAM-1, and sE-selectin) and vascular endothelial growth factor in patients with rheumatoid arthritis. Scand. J. Rheumatol. 2009;38(6):439 444. https://doi.org/10.3109/03009740903079321

14. Dessein P. H., Joffe B. I., Singh S. Biomarkers of endothelial dysfunction, cardiovascular risk factors and atherosclerosis in rheumatoid arthritis. Arthritis Res. Ther. 2005;7(3):R634. https://doi.org/10.1186/ar1717

15. Klimiuk P. A., Fiedorczyk M., Sierakowski S., Chwiecko J. Soluble cell adhesion molecules (sICAM-1, sVCAM-1, and SE-selectin) in patients with early rheumatoid arthritis. Scand. J. Rheumatol. 2007;36(5):345-350. https://doi.org/10.1080/03009740701406460

16. Gonzalez-Juanatey C., Llorca J., Sanchez-Andrade A., Garcia-Porrua C., Martin J. [et al.] Short-term adalimumab therapy improves endothelial function in patients with rheumatoid arthritis refractory to infliximab. Clin. Exp. Rheumatol. 2006;24(3):309-312.

17. Oranskiy S. P., Yeliseyeva L. N. Serum concentration of immune, endocrine and endothelial biomarkers in patients with rheumatoid arthritis associated with different variants of metabolic status treated with infliximab. Medical news of North Caucasus. 2016:11(2):139-142. https://doi.org/10.14300/mnnc.2016.11019

18. Shu Q., Amin M. A., Ruth J. H., Campbell P. L., Koch A. E. Suppression of endothelial cell activity by inhibition of TNF alpha. Arthritis Res. Ther. 2012:14(2):R88. https://doi.org/10.1186/ar3812

19. Komarova E. B., Rebrov B. A., Knyazeva A. K. An angiotensin-converting enzyme inhibitor in the combination treatment of rheumatoid arthritis. Sovremennaya Revmatologiya - Modern Rheumatology Journal. 2017;11(3):7276. (In Russ.). https://doi.org/10/14412/1996-7012-2017-3-72-76

20. Nozaki K., Hikiami H., Goto H., Nakagawa T., Shibahara N. [et al.] Keishibukuryogan (Gui-Zhi-Fu-Ling-Wan), a Kampo Formula, decreases disease activity and soluble vascular adhesion molecule- 1 in patients with rheumatoid arthritis. eCAM. 2006;3(3):359-364. https://doi.org/10.1093/ecam/nel025

21. Elshabrawy H. A., Chen Z., Volin M. V., Ravella S., Virupannavar S. [et al.] The pathogenic role of angiogenesis in rheumatoid arthritis. Angiogenesis. 2015;18(4):433-448. https://doi.org/10.1007/s10456-015-9477-2

22. Hodkinson B., K. Magomero R., Tikly M. Combination leflunomide and methotrexate in refractory rheumatoid arthritis: a biologic sparing approach. Ther. Adv. Musculoskelet. Dis. 2016;8(5):172-179. https://doi.org/10.1177/1759720X16664324

23. Tanaka H., Kanazawa M., Kawakami T. Efficacy and safety of tocilizumab therapy in rheumatoid arthritis: prevalence and predictive factors of sustained remission. Ann. Rheuma. Dis. 2013;72(3):453.

24. Canhão H., Rodrigues A. M., Mourão A. F., Martins F., Santos M. J. [et al.] Comparative effectiveness and predictors of response to tumour necrosis factor inhibitor therapies in rheumatoid arthritis. Rheumatology. 2012;51(11):20202026. https://doi.org/10.1093/rheumatology/kes 184

25. Wevers-de Boer K., Visser K., Heimans L., Ronday H. K, Molenaar E. [et al.] Remission induction therapy with methotrexate and prednisone in patients with early rheumatoid and undifferentiated arthritis (the IMPROVED study). Ann. Rheum. Dis. 2012;71(9):1472-1477.

\section{About authors:}

Koroy Pavel Vladimirovich, MD, PhD, Professor of Department of Hospital Therapy; tel.: +79282938068; e-mail: paule75@yandex.ru

Sarithala Vijaya Jawahar, MD, Post-Graduate Student; tel.: +79887422198; e-mail: jay_sv2006@yahoo.com

Yagoda Alexander Valentinovich, MD, PhD, Professor, Honored Worker of Science of Russian Federation, Head of Department of Hospital Therapy; 